\title{
PENGARUH KARAKTERISTIK INDIVIDU, INTELEGENSI DAN KOMPETENSI SOSIAL TERHADAP KINERJA DAN PENGEMBANGAN KARIR DOSEN \\ (Studi Kasus Pada Universitas Islam Madura Tahun 2017)
}

\author{
Qaiyim Asy'ari \\ Dosen Institut Agama Islam Al-Khairat Pamekasan Madura \\ E-mail: qaiyim90@gmail.com
}

\section{Abstrak}

Menurut Gibson, dkk (1997), terdapat 3 (tiga) kelompok variabel yang mempengaruhi kinerja dan perilaku seseorang, yaitu variabel individu, variabel organisasi, dan variabel psikologis. Kinerja dosen tidak hanya dilihat dari kemampuan kerja yang sempurna, tetapi juga kemampuan menguasai dan mengelola diri sendiri serta kemampuan dalam membina hubungan dengan orang lain (Martin, 2000). Kemampuan tersebut oleh Daniel Goleman disebut dengan Emotional Intelligence atau kecerdasan emosi. Salah satu bentuk kecerdasan lain yang saat ini tengah popular adalah kecerdasan sipiritual. kecerdasan spiritual mampu mengintegrasikan dua kemampuan lain yang sebelumnya telah disebutkan yaitu IQ dan EQ. Selain faktor Intelgency dan karakteristik individu yaitu faktor kempetensi sosial. Yaitu suatu kemampuan individu dalam berinteraksi secara efektif dengan lingkungan. Metode penelitian yang digunakan yaitu penelitian kuantitatif dengan menggunakan teknik analisis regresi linear berganda, Populasi dalam penelitian ini adalah seluruh dosen di Universitas Islam Madura. Adapun hasil dari penelitian ini yaitu; 1) Variabel karakteristik individu, Variabel kecerdasan, Variabel kompetensi sosial berpengaruh secara parsial dan signifikan terhadap kinerja dosen dan pengembangan karir dosen. 2) Variabel karakteristik individu, kecerdasan, kompetensi sosial sama sama berpengaruh secara simultan terhadap kinerja dosen dan pengembangan karir dosen.

\section{Kata Kunci: Karakteristik Individu, Intelegensi, Kompetensi Sosial, Dan Pengembangan Karir}

\section{Abstract}

According to Gibson, et al (1997), there are 3 (three) groups of variables that affect a person's performance and behavior, namely individual variables, organizational variables, and 
psychological variables. Lecturer performance is not only seen from the ability to work perfectly, but also the ability to master and manage themselves and the ability to build relationships with others (Martin, 2000). This ability by Daniel Goleman is called Emotional Intelligence or emotional intelligence. Another form of intelligence that is currently popular is spiritual intelligence. spiritual intelligence is able to integrate two other abilities previously mentioned namely IQ and EQ. In addition to intelligence and individual characteristics, the factors are social competence. That is an individual's ability to interact effectively with the environment. The research method used is quantitative research using multiple linear regression analysis techniques, the population in this study were all lecturers at Madura Islamic University. The results of this study are; 1) Variables of individual characteristics, Variables of intelligence, Variables of social competence have a partial and significant effect on the performance of lecturers and career development of lecturers. 2) Variables of individual characteristics, intelligence, social competence are equally influential simultaneously on the performance of lecturers and career development of lecturers.

\section{Keywords: Individual Characteristics, Intelligence, Social Competence, and Career Development}

\section{A. PENDAhUluan}

Di dalam penyelenggaraan sistem pendidikan tinggi dewasa ini di hadapkan kepada banyak persoalan/kelemahan apabila di bandingkan dengan harapan (expectations) masyarakat (stakeholders) dan juga apabila di bandingkan dengan perguruan tinggi negara-negara lain yang masih samasama dalam kategori negara berkembang. Salah satu kelemahannya adalah rendahnya kinerja dosen karena berbagai faktor, baik faktor internal dosen sendiri maupun faktor eksternal atau faktor lingkungan (Isham, 2004:4).

Menurut Gibson, dkk (1997), terdapat 3 (tiga) kelompok variabel yang mempengaruhi kinerja dan perilaku seseorang, yaitu variabel individu (meliputi:kemampuan dan keterampilan, latar belakang individu: tingkat sosial, 
pengalaman,umur, etnis, jenis kelamin), variabel organisasi (meliputi: sumber daya, kepemimpinan, imbalan, struktur, desain pekerjaan) dan variabel psikologis (meliputi: persepsi, sikap, belajar, kepribadian, motivasi). Darma (2005) menambahkan, bahwa terdapat beberapa karakteristik individu yang mempengaruhi kinerja, meliputi: umur, jenis kelamin, pendidikan, lamakerja,penempatan kerja dan lingkungan kerja (rekan kerja, atasan, organisasi, penghargaan dan imbalan).

Kinerja dosen tidak hanya dilihat dari kemampuan kerja yang sempurna, tetapi juga kemampuan menguasai dan mengelola diri sendiri serta kemampuan dalam membina hubungan dengan orang lain (Martin, 2000). Kemampuan tersebut oleh Daniel Goleman disebut dengan Emotional Intelligence atau kecerdasan emosi. Goleman (2000) melalui penelitiannya mengatakan bahwa kecerdasan emosi menyumbang $80 \%$ dari faktor penentu kesuksesan sesorang, sedangkan $20 \%$ yang lain ditentukan oleh IQ (Intelligence Quotient).

Salah satu bentuk kecerdasan lain yang saat ini tengah popular adalah kecerdasan sipiritual. Kecerdasan spiritual memungkinkan seseorang untuk berpikir kreatif, berwawasan jauh, membuat atau bahkan mengubah aturan, yang membua torang tersebut dapat bekerjal ebih baik.Secara singkat kecerdasan spiritual mampu mengintegrasikan dua kemampuan lain yang sebelumnya telah disebutkan yaitu IQ dan EQ (Idrus, 2002).

Selain faktor Intelgency dan karakteristik individu yaitu faktor kempetensi sosial. Yaitu suatu kemampuan individu dalam berinteraksi secara efektif dengan lingkungan dan 
memberi pengaruh pada orang lain demi mencapai tujuan dalam konteks sosial tertentu yang disesuaikan dengan budaya, lingkungan, situasi yang dihadapi serta nilai yang dianut oleh individu disebut sebagai kompetensi sosial.

\section{B. PEMBAHASAN}

\section{Karakteristik Individu}

Karater individu merupakan penjabaran dari sikap dan minat serta kebutuhan yang di bawa seseorang atau individu dalam pelaksanaan kerja, Karakter individu satu dengan individu yang lain akan berbeda dan menyebabkan mutivasi dalam situasi kerja juga berbeda (Endang 2006 ;37).

Robbin (dalam Endang 2006;37) menjelasan bahwa karateristik individu yang paling mudah diamati yang mempengaruhi perilaku berorganisasinya adalah karakteristik biografis yaitu kajian mengenai umur, jenis kelamin, status perawinan, pengalaman kerja, jumlah tanggungan, dan tingkat pendidikan.

Menurut Stoner (dalam Endang 2006; 38) Karekteristik individu yakni, minat, sikap dan kebutuhan. Minat adalah kecendrungan pegawai/pekerja/dosen terkonsentrasi dalam satuan pengalaman/aktivitas tertentu dan kecendrungannya untuk mau mengembangkannya atau yang membuat seseorang merasa senang atas suatu obyek atau situasi.

Indikator karakteristik individu menurut teori Path-Goal dalam Peoni (2014: 15), yaitu sebagai berikut:

a. Letak Kendali (Locus of Control); Hal ini berkaitan dengan keyakinan individu sehubungan dengan 
penentuan hasil; Individu yang mempunyai letak kendali internal meyakini bahwa hasil (reward) yang mereka peroleh didasarkan pada usaha yang mereka lakukan sendiri. Sedangkan mereka yang cenderung letak kendali eksternal meyakini bahwa hasil yang mereka peroleh dikendalikan oleh kekuatan di luar kontrol pribadi mereka. Orang yang internal cenderung lebih menyukai gaya kepemimpinan yang participative, sedangkan eksternal umumnya lebih menyenangi gaya kepemimpinan directive.

b. Kesediaan untuk Menerima Pengaruh (Authoritarianism); Kesediaan orang untuk menerima pengaruh dari orang lain. Bawahan yang tingkat authoritarianism yang tinggi cenderung merespon gaya kepemimpinan yang directive, sedangkan bawahan yang tingkat authoritarianism rendah cenderung memilih gaya kepemimpinan partisipatif.

Kemampuan (Abilities); Kemampuan dan pengalaman bawahan akan mempengaruhi apakah mereka dapat bekerja lebih berhasil dengan pemimpin yang berorientasi prestasi (achievementoriented) yang telah menentukan tantangan sasaran yang harus dicapai dan mengharapkan prestasi yang tinggi, atau pemimpin yang supportive yang lebih suka memberi dorongan dan mengarahkan mereka. Bawahan yang mempunyai kemampuan yang tinggi cenderung memilih gaya kepemimpinan achievementoriented, sedangkan bawahan yang mempunyai kemampuan rendahcenderung memilih pemimpin yang supportive. 


\section{Kecerdasan Intelektual}

Kecerdasan dalam arti umum adalah suatu kemampuan umum yang membedakan kualitas orang yang satu dengan orang yang lain (Joseph, 1978: 8). Kecerdasan intelektual lazim disebut dengan inteligensi. Istilah ini dipopulerkan kembali pertama kali oleh Francis Galton, seorang ilmuwan dan ahli matematika yang terkemuka dari Inggris (Joseph, 1978: 19). Inteligensi adalah kemampuan kognitif yang dimiliki organisme untuk menyesuaikan diri secara efektif pada lingkungan yang kompleks dan selalu berubah serta dipengaruhi oleh faktor genetik (Galton, dalam Joseph, 1978,).

Wiramiharja, (2003:73) mengemukakan indikatorindikator dari kecerdasan intelektual. Penelitiannya tentang kecerdasan ialah menyangkut upaya untuk mengetahui keeratan besarnya kecerdasan dan kemauaan terhadap prestasi kerja. Ia meneliti kecerdasan dengan menggunakan alat tes kecerdasan yang diambil dari tes inteligensi yang dikembangkan oleh Peter Lauster, sedangkan pengukuran besarnya kemauan dengan menggunakan alat tes Pauli dari Richard Pauli, khusus menyangkut besarnya penjumlahan. Ia menyebutkan tiga indikator kecerdasan intelektual yang menyangkut tiga domain kognitif. Ketiga indikator tersebut adalah:

a. Kemampuan figur yaitu merupakan pemahaman dan nalar dibidang bentuk.

b. Kemampuan verbal yaitu merupakan pemahaman dan nalar dibidang bahasa. 
c. Pemahaman dan nalar dibidang numerik atau yang berkaitan dengan angka biasa disebut dengan kemampuan numeric.

\section{Kecerdasan Emosional}

Orang yang pertama kali mengungkapkan adanya kecerdasan lain selain akademik yang dapat mempengaruhi keberhasilan sesorang adalah Gardner. Kecerdasan lain itu disebut dengan emotional intelligence atau kecerdasan emosi (Goleman, 2000: 51).

Kecerdasan emosi merupakan kemampuan untuk menggunakan emosi secara efektif dalam mengelola diri sendiri dan mempengaruhi hubungan dengan orang lain secara positif. Menurut Salovey dan Mayer, 1999 (handbook Emotional Intelligence training, prime consulting,) kecerdasan emosi adalah kemampuan untuk merasakan emosi, menerima dan membangun emosi dengan baik, memahami emosi dan pengetahuan emosional sehingga dapat meningkatkan perkembangan emosi dan intelektual.

Kecerdasan Emosi dapat diukur dari beberapa aspek-aspek yang ada. Goleman (2001: 42-43) mengemukakan lima kecakapan dasar dalam kecerdasan Emosi, yaitu:

a. Self awareness

Merupakan kemampuan sesorang untuk mengetahui perasaan dalam dirinya dan efeknya serta menggunakannya untuk membuat keputusan bagi diri sendiri, memiliki tolak ukur yang realistis, atau kemampuan diri dan mempunyai kepercayaan diri yang 
Qaiyim Asy'ari : Pengaruh Karakteristik Individu, Intelegensi dan Kompetensi Sosial

kuat lalu mengkaitkannya dengan sumber penyebabnya.

b. Self management

Yaitu merupakan kemampuan menangani emosinya sendiri, mengekspresikan serta mengendalikan emosi, memiliki kepekaan terhadap kata hati, untuk digunakan dalam hubungan dan tindakan sehari-hari.

c. Motivation

Motivasi adalah kemampuan menggunakan hasrat untuk setiap saat membangkitkan semangat dan tenaga untuk mencapai keadaan yang lebih baik serta mampu mengambil inisiatif dan bertindak secara efektif, mampu bertahan menghadapi kegagalan dan frustasi.

d. Empati (social awareness)

Empati merupakan kemampuan merasakan apa yang dirasakan oleh orang lain, mampu memahami perspektif orang lain, dan menimbulkan hubungan saling percaya serta mampu menyelaraskan diri dengan berbagai tipe individu

e. Relationship management

Merupakan kemampuan menangani emosi dengan baik ketika berhubungan dengan orang lain dan menciptakan serta mempertahankan hubungan dengan orang lain, bisa mempengaruhi, memimpin, bermusyawarah, menyelesaikan perselisihan dan bekerja sama dalam tim.

\section{Kecerdasan Spiritual}

Pada masa kini orang mulai mengenal istilah kecerdasan lain disamping kedua kecerdasan diatas, yaitu kecerdasan spiritual. Zohar dan Marshal (2001: 37) 
mendefinisikan kecerdasan spiritual sebagai rasa moral, kemampuan menyesuaikan aturan yang kaku dibarengi dengan pemahaman dan cinta serta kemampuan setara untuk melihat kapan cinta dan pemahaman sampai pada batasannya, juga memungkinkan kita bergulat dengan ihwal baik dan jahat, membayangkan yang belum terjadi serta mengangkat kita dari kerendahan. Kecerdasan tersebut menempatkan perilaku dan hidup kita dalam konteks makna yang lebih luas dan kaya, kecerdasan untuk menilai bahwa tindakan atau jalan hidup sesorang lebih bernilai dan bermakna (Zohar dan Marshal, 2000: 25).

Sukidi (2002: 94) mengemukakan tentang nilai-nlai dari kecerdasan spritual berdasarkan komponen-komponen dalam SQ yang banyak dibutuhkan dalam dunia bisnis, diantaranya adalah:

a. Mutlak Jujur

Kata kunci pertama untuk sukses di dunia bisnis selain berkata benar dan konsisten akan kebenaran adalah mutlak bersikap jujur. Ini merupakan hukum spiritual dalam dunia usaha.

b. Keterbukaan

Keterbukaan merupakan sebuah hukum alam di dalam dunia usaha, maka logikanya apabila sesorang bersikap fair atau terbuka maka ia telah berpartisipasi di jalan menuju dunia yang baik

c. Pengetahuan diri

Pengetahuan diri menjadi elemen utama dan sangat dibutuhkan dalam kesuksesan sebuah usaha karena 
dunia usaha sangat memperhatikan dalam lingkungan belajar yang baik.

d. Fokus pada kontribusi

Dalam dunia usaha terdapat hukum yang lebih mengutamakan memberi daripada menerima. Hal ini penting berhadapan dengan kecenderungan manusia untuk menuntut hak ketimbang memenuhi kewajiban. Untuk itulah orang harus pandai membangun kesadaran diri untuk lebih terfokus pada kontribusi

e. Spiritual non dogmatis

Komponen ini merupakan nilai dari kecerdasan spiritual dimana didalamnya terdapat kemampuan untuk bersikap fleksibel, memiliki tingkat kesadaran yang tinggi, serta kemampuan untuk menghadapi dan memanfaatkan penderitaan, kualitas hidup yang diilhami oleh visi dan nilai.

\section{Kompetensi Sosial}

Kompetensi adalah suatu kemampuan untuk melaksanakan atau melakukan suatu pekerjaan atau tugas yang dilandasi dengan keterampilan dan pengetahuan serta didukung oleh sikap kerja yang dituntut oleh pekerjaan (Wibowo, 2008 : 86). Enceng dkk (2008) menyatakan bahwa kompetensi merupakan pengetahuan, keterampilan, dan kemampuan yang dikuasai oleh seseorang yang telah menjadi bagian dari dirinya, sehingga ia dapat melakukan perilaku-perilaku kognitif, afektif, dan psikomotorik dengan sebaik-baiknya.

Menurut Spencer \& Spencer (1993:35) Indikator indikator kompetensi sosial terdiri dari:

a. Kemampuan mempengaruhi orang lain 
Tingkat kemampuan karyawan dalam meyakinkan orang lain agar efektif dan terbuka dalam berbagi pengetahuan.

b. Kemampuan membangun kerja sama Tingkat kemampuan karyawan dalam membangun jaringan kerjasama agar tetap akrab dan hangat.

c. Kemampuan mengarahkan rekan kerja Tingkat kemampuan karyawan dalam mempengaruhi rekan/bawahan dengan strategi dan hubungan interpersonal.

d. Kemampuan dalam bekerja sama

Tingkat kemampuan karyawan dalam bekerja sama secara koperatif dalam suatu tim.

e. Kemampuan dalam memimpin

Tingkat kemampuan karyawan untuk berperan sebagai pemimpin tim.

\section{Kinerja}

Kinerja dalam bahasa latin berasal dari kata Job performance atau performance yang mempunyai arti prestasi kerja atau prestasi sesungguhnya yang dicapai oleh seseorang (Mangkunegara, 2008:67). Biasanya orang yang kinerjanya tinggi disebut orang yang produktif dan sebaliknya orang yang tingkat kinerjanya tidak mencapai tingkat standar dikatakan sebagai orang yang tidak produktif atau berperforma rendah.kinerja mempunyai makna yang lebih luas, bukan hanya hasil kerja, tetapi termasuk bagaimana proses pekerjaan berlangsung (Wibowo: 2007).

Menurut Hasibuan (2002:160) kinerja adalah merupakan suatu hasil kerja yang dicapai seseorang dalam 
melaksanakan tugas-tugasnya atas kecakapan, usaha dan kesempatan. Simamora (1997:339) mengemukakan bahwa untuk mencapai agar organisasi berfungsi secara efektif dan sesuai dengan sasaran organisasi, maka organisasi harus memiliki kinerja karyawan yang baik yaitu dengan melaksanakan tugas-tugasnya dengan cara yang handal. Mangkunegara (2006:67) berpendapat bahwa kinerja (prestasi kerja) adalah hasil kerja secara kualitas dan kuantitas yang dicapai oleh seorang pegawai dalam melaksanakan tugasnya sesuai dengan tanggung jawab yang diberikan kepadanya.

Indikator kinerja karyawan menurut Mathis dan Jackson (2006:378) adalah sebagai berikut:

a. Kuantitas

Kuantitas merupakan jumlah yang dihasilkan dinyatakan dalam istilah seperti jumlah unit, jumlah siklus aktivitas yang diselesaikan. Kuantitas yang diukur dari persepsi pegawai terhadap jumlah aktivitas yang ditugaskan beserta hasilnya.

b. Kualitas

Kualitas adalah ketaatan dalam prosedur, disiplin, dedikasi. Tingkat dimana hasil aktivitas yang dikehendaki mendekati sempurna dalam arti menyesuaikan beberapa cara ideal dari penampilan aktivitas, maupun memenuhi tujuan-tujuan yang diharapkan dari suatu aktivitas. Kualitas kerja diukur dari persepsi pegawai terhadap kualitas pekerjaan yang dihasilkan serta kesempurnaan tugas terhadap ketrampilan dan kemampuan pegawai. 
c. Keandalan

Keandalan adalah kemampuan untuk melakukan pekerjaan yang disyaratkan dengan supervisi minimum.

d. Kehadiran

Kehadiran adalah keyakinan akan masuk kerja setiap hari dan sesuai dengan jam kerja.

e. Kemampuan bekerja sama

Kemampuan bekerja sama adalah kemampuan seorang tenaga kerja untuk bekerja bersama dengan orang lain dalam menyelesaikan suatu tugas dan pekerjaan yang telah ditetapkan sehingga mencapai daya guna dan hasil guna yang sebesar-besarnya.

\section{Pengembangan Karir}

Menurut Simamora dalam Shaputra dan Hendriani (2015: 5) pengembangan karir meliputi perencanaan karir dan manajemen karir. Perencanaan karir adalah proses yang dilalui oleh individu karyawan untuk mengidentifikasikan dan mengambil langkah - langkah untuk mencapai tujuan karirnya. Manajemen karir adalah proses yang dilakukan oleh organisasi untuk memilih, menilai, menugaskan, dan mengembangkan para karyawannya guna menyediakan suatu kumpulan orang- orang kompeten untuk memenuhi kebutuhan dimasa depan.

Menurut Handoko dalam Shaputra dan Hendriani (2015: 6), tujuan dari pengembangan karir adalah:

a. Untuk mengembangkan para karyawan agar dapat dipromosikan

b. Untuk mengungkapkan potensi karyawan 
c. Untuk mendorong pertumbuhan Untuk mengurangi penimbunan

d. Untuk memuaskan kebutuhan karyawan

e. Untuk meningkatkan karir

Indikator Pengembangan karir Menurut Siagian dalam Shaputra dan Hendriani (2015: 7), berbagai indikator yang perlu dipertimbangkan dalam pengembangan karir adalah sebagai berikut:

a. Perlakuan yang adil dalam berkarir; Perlakuan yang adil itu hanya bisa terwujud apabila kriteria promosi didasarkan pada pertimbanganpertimbangan yang objektif, rasional dan diketahui secara luas dikalangan pegawai.

b. Keperdulian para atasan langsung Para karyawan; pada umumnya mendambakan keterlibatan atasan langsung mereka dalam perencanaan karir masing masing. Salah satu bentuk keperdulian itu adalah memberikan umpan balik kepada para pegawai tentang pelaksanaan tugas masing - masing sehingga para pegawai tersebut mengetahui potensi yang perlu diatasi. Pada gilirannya umpan balik itu merupakan bahan penting bagi para pegawai mengenai langkah awal apa yang perlu diambilnya agar kemungkinannya untuk dipromosikan menjadi lebih besar.

c. Informasi tentang berbagai peluang promosi Para pegawai; pada umumnya mengharapkan bahwa mereka memiliki akses kepada informasi tentang berbagai peluang untuk diprom osikan. Akses ini sangat penting terutama apabila lowongan yang 
tersedia diisi melalui proses seleksi internal yang sifatnya kompetitif . Jika akses demikian tidak ada atau sangat terbatas para pekerja akan $\mathrm{m}$ udah beranggapan bahwa prinsip keadilan dan kesamaan dan kesempatan untuk dipertimbangkan, untuk dipromosikan tidak diterapkan dalam organisasi.

d. Adanya minat untuk dipromosikan. Pendekatan yang tepat digunakan dalam hal menumbuhkan minat para pekerja untuk pengembangan karir ialah pendekatan yang fleksibel dan proaktif. Artinya, minat untuk mengembangkan karir sangat individualistik sifatnya. Seorang pekerja memperhitungkan berbagai faktor seperti usia, jenis kelamin, jenis dan sifat pekerjaan sekarang, pendidikan dan pelatihan yang ditempuh, juml ah tanggungan dan berbagai variabel lainnya. Berbagai faktor tersebut dapat berakibat pada besarnya minat sesorang mengembangkan karirnya.

e. Tingkat kepuasaan. Meskipun secara umum dapat dikatakan bahwa setiap orang ingin meraih kemajuan, termasuk dalam meniti karir, ukuran keberhasilan yang digunakan memang berbedabeda. Perbedaan tersebut merupakan akibat tingkat kepuasaan, dan dalam konteks terakhir tidak selalu berarti keberhasilan mencapai posisi yang tinggi dalam organisasi.

\section{Kerangka Konseptual Dan Hipotesis Penelitian}

Berdasarkan teori yang dikemukakan sebelumnya, maka disusunlah kerangka proses berfikir yang ditunjukkan dalam gambar berikut: 
Gambar 1. Kerangka Proses Berpikir

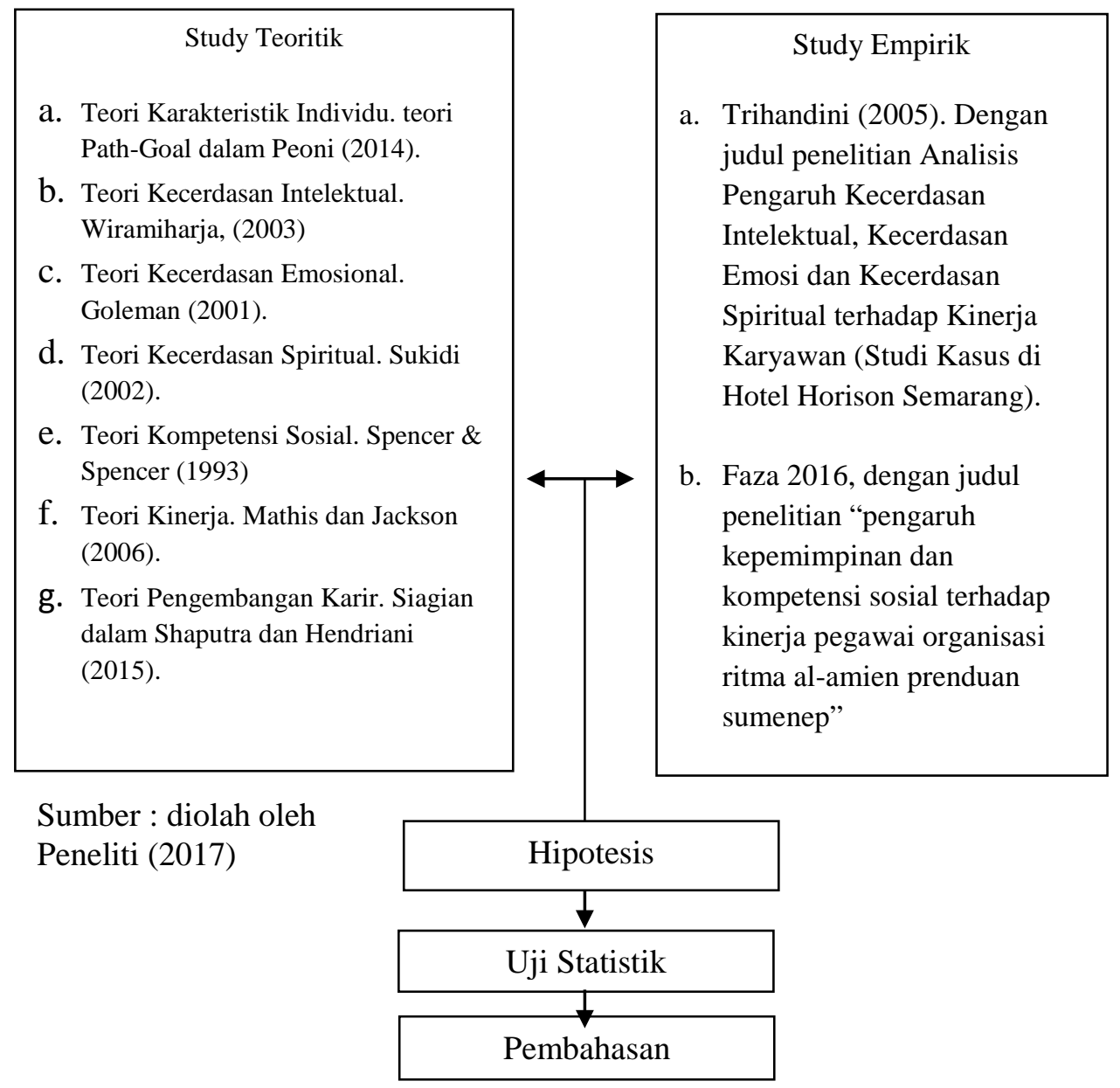

Penelitian ini membutuhkan teori mengenai karakteristik individu, intelgence yang terdiri dari kecerdasan intelktual, kecerdasan emosional, dan kecerdasan spiritual. Teori kompetensi sosial. Teori kinerja dan teori pengembangan karir. Teori ini perlu dipelajari karena akan banyak membantu proses analis. Oleh karena itu proses berfikir yang terkandung dalam study teoritis mengandung proses berfikir deduktif artinya seorang peneliti akan menganalisis dan menjawab permasalahan 
serta mengambil kesimpulan dari yang bersifat umum ke arah yang lebih khusus. Selain study teoritik, penelitian ini memerlukan study empiris yang relevan yang mengandung proses berfikir induktif artinya peneliti menganalisis dari yang bersifat khusus ke arah yang bersifat umum.

Berdsarkan kerangka proses berfikir, maka dapat disusun kerangka konseptual penelitian yang dapat ditunjukkan pada gambar dibawah ini.

Gambar 2. Kerangka konseptual Penelitian

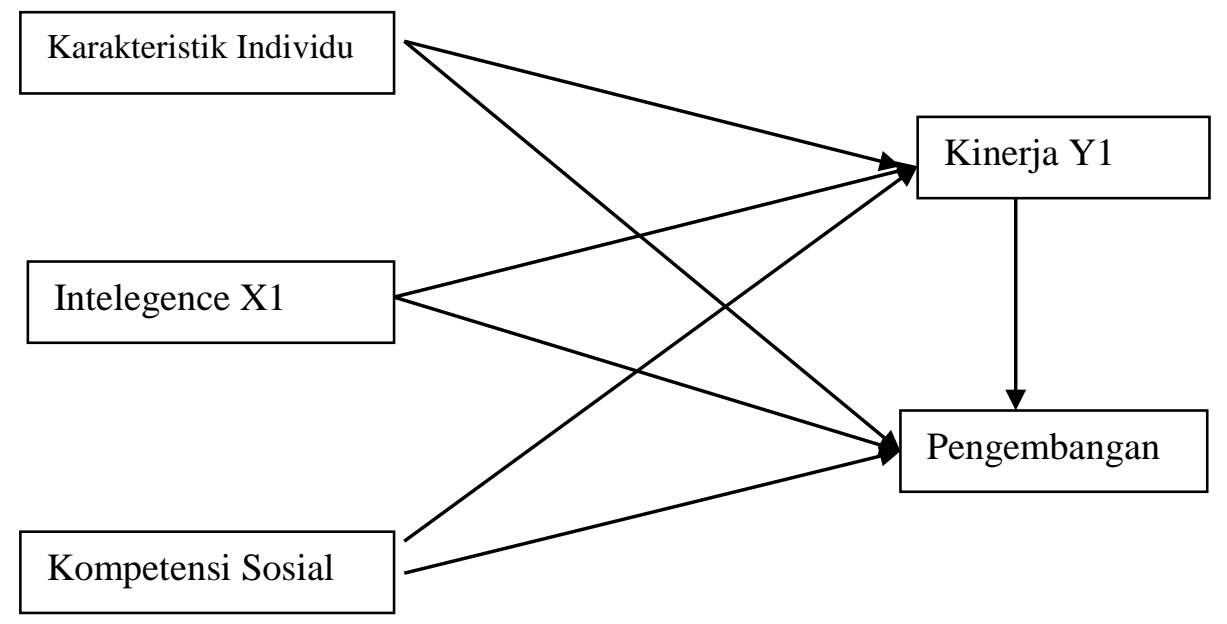

Berdasarkan rumusan masalah dan tujuan penelitian, maka hipotesis dalam penelitian iniyaitu:

a. Faktor karakeristik Individu berpengaruh signifikan terhadap kinerja dosen di Universitas Islam Madura?

b. Faktor intelegency berpengaruh signifikan terhadap kinerja dosen di Universitas Islam Madura?

c. Faktor kompetensi sosial berpengaruh signifikan terhadap kinerja dosen di Universitas Islam Madura?

d. Faktor karakeristik Individu berpengaruh signifikan terhadap pengembangan karir dosen ? 
e. Faktor intelegence berpengaruh signifikan terhadap pengembangan karir dosen di Universitas Islam Madura?

f. Faktor kompetensi sosial berpengaruh signifikan terhadap pengembangan karir dosen di Universitas Islam Madura?

g. faktor karakeristik Individu, intelegence, dan kompetensi sosial secara bersama-sama berpengaruh signifikan terhadap kinerja dan pengembangan karir dosen di Universitas Islam Madura?

\section{Metode Penelitian}

a. Populasi

Populasi adalah wilayah generalisasi yang terdiri atas obyek/subyek yang mempunyai kualitas dan karakteristik tertentu yang ditetapkan oleh peneliti untuk dipelajari kemudian ditarik kesimpulannya (Sugiyono, 2011:80). Populasi dalam penelitian ini adalah seluruh dosen di Universitas Islam Madura.

Tabel 1. Jumlah Populasi dosen di Universitas Islam Madura

\begin{tabular}{|c|c|c|}
\hline No. & Fakultas & Populasi \\
\hline 1. & Agama Islam & 12 \\
\hline 2. & Teknik & 9 \\
\hline 3. & Matematika dan IPA & 10 \\
\hline 4. & Ekonomi & 15 \\
\hline 5. & Pertanian & 9 \\
\hline 6. & Hukum & 11 \\
\hline 7. & Keguruan dan Ilmu & 16 \\
\hline 8 & Pendidikan & 12 \\
\hline & Kebidanan & 94 \\
\hline
\end{tabular}

Sumber : Data BAAK Universitas Islam Madura 
b. Jenis Data

1) Data Primer

Data primer adalah data yang diperoleh dari sumber pertama baik dari individu maupun perwakilan kelompok.

2) Data Sekunder

Data sekunder digunakan untuk melengkapi data yang dibutuhkan. Data sekunder yang digunakan dalam penelitian ini adalah data jumlah dosen di Universitas Islam Madura.

c. Sumber Data

Sumber data yang digunakan dalam penelitian ini hanyalah sumber data internal. Sumber data internal adalah sumber data yang didapat dari organisasi dimana penelitian dilakukan. Penelitian ini sumber data internalnya adalah dosen di Universitas Islam Madura.

d. Teknik Pengumpulan Data

Teknik pengumpulan data yaitu cara yang digunakan peneliti dalam mengumpulkan data yang akan digunakan dalam penelitian. Teknik pengumpulan data yang digunakan dalam penelitian ini, yaitu:

1) Studi Literatur

Studi literatur adalah pengumpulan data dan informasi melalui buku-buku, makalah, internet dan karya ilmiah lainnya guna memperoleh informasi yang berhubungan dengan teori-teori dan konsepkonsep yang berkaitan dengan masalah peneltian. 
2) Observasi

Menggunakan metode ini sangat penting, karena untuk mengetahui secara langsung kondisi di lapangan.

3) Kuesioner

Kuesioner merupakan teknik pengumpulan data yang dilakukan dengan cara memberi seperangkat pertanyaan atau pernyataan tertulis kepada responden untuk dijawabnya. Kuesioner merupakan teknik pengumpulan data yang efisien bila peneliti tahu dengan pasti variabel yang akan diukur dan tahu apa yang bisa diharapkan dari responden. Selain itu, kuesioner juga cocok digunakan bila jumlah responden cukup besar. Kuesioner dapat berupa pertanyaan atau pernyataan dan dapat diberikan kepada responden secara langsung.

e. Teknik Analisis Data

1) Uji Validitas

Validitas adalah suatu ukuran yang menunjukkan tingkat-tingkat kevalidan atau kesahihan suatu instrumen (Suharsimi, 2006:168). Suatu instrumen dapat dikatakan valid apabila mampu mengukur apa yang diinginkan dalam mengungkapkan data dari variabel yang diteliti secara tepat. Tinggi rendahnya validitas instrumen menunjukkan sejauh mana data yang terkumpul tidak menyimpang dari gambaran tentang variabel yang dimaksud. Pengukuran validitas ini dengan menggunakan koelasi product moment. Jika koefisien korelasi (R) yang diperoleh $\geq$ dari pada koefisien tabel nilai-nilai 
kritis $R$, yaitu taraf signifikasi 5\% atau 1, instrumen tes yang di uji cobakan tersebut dapat dinyatakan valid (Sugiyono dalam Yuliana : 2015).

2) Uji Reliabilitas

Menurut Ghozali dalam Mudawi (2015), reliabilitas adalah tingkat seberapa besar suatu pengukur mengukur dengan stabil dan konsisten. Reliabilitas merujuk pada pengertian bahwa suatu instrument cukup dapat dipercaya untuk dapat digunakan sebagai alat pengumpul data karena intrumen tersebut sudah baik. Uji reliabilitas berkaitan dengan masalah adanya kepercayaan terhadap instrument. Suatu instrument dapat memiliki tingkat kepercayaan yang tinggi (konsisten) jika hasil dari pengujian instrument tersebut menunjukkan hasil yang tetap sehingga dapat dikatakan bahwa pengujian reliabilitas instrument dalam mengukur variabel yang sama dengan hasil yang tidak berubah. Suatu konstruk dikatakan handal atau reliabel jika memberikan nilai a >0,60 (Nunally dalam Imam Ghozali, 2005)

3) Uji Normalitas

Uji normalitas bertujuan untuk menguji apakah dalam model regresi, variabel penggangu atau residual memiliki distribusi normal atau tidak. Uji T dan uji $F$ mengasumsikan bahwa nilai residual mengikuti distribusi normal. Ada dua cara untuk mendeteksi apakah residual berdistribusi normal atau tidak yaitu dengan analisis grafik dan uji statistik. (Ghozali, 2011: 160). 
4) Uji Hipotesis Pertama (T Parsial)

Tabel 2. Perbandingan t-tabel dengan t-hitung pengaruh karakteristik individu terhadap kinerja

\begin{tabular}{|c|c|c|c|}
\hline Variabel & t-tabel & t-hitung & keterangan \\
\hline Karakteristik individu (X1) & 1.671 & 3.076 & Signifikan \\
Intelegence (X2) & 1.671 & 2.532 & Signifikan \\
Kompetensi sosial (X3) & 1.671 & 5.770 & Signifikan \\
\hline
\end{tabular}

a) Berdasarkan pada perbandingan antara t-hitung dengan t-tabel untuk variabel karakteristik Individu (X1) menunjukkan nilai t-hitung sebesar $3.076>$ t-tabel 1.671. maka Ho ditolak dan $\mathrm{H} 1$ diterima. Artinya secara parsial variabel karakteristik individu (X1) berpengaruh signifikan terhadap variabel kinerja dosen (Y1).

b) Berdasarkan pada perbandingan antara t-hitung dengan t-tabel untuk variabel Intellegence (X2) menunjukkan nilai t-hitung sebesar $2.532>\mathrm{t}-$ tabel 1.671. maka Ho ditolak dan H1 diterima. Artinya secara parsial variabel Intellegence (X2) berpengaruh signifikan terhadap variabel kinerja dosen (Y1).

c) Berdasarkan pada perbandingan antara t-hitung dengan t-tabel untuk variabel kompetensi sosial (X3) menunjukkan nilai t-hitung sebesar $5.770>$ t-tabel 1.671. maka Ho ditolak dan $\mathrm{H} 1$ diterima. Artinya secara parsial variabel kompetensi sosial (X3) berpengaruh signifikan terhadap variabel kinerja dosen (Y1).

Hasil ini menunjukkan bahwa kinerja dipengaruhi oleh karakteristik individu. Seseorang yang memiliki 
karakteristik yang baik akan sangat mendukung terhadap keberhasilannya dalam dunia kerja atau dengan kata lain akan mendukung terhadap kinerjanya dalam suatu instansi. Seperti pernyataan yang diungkapkan oleh (Endang 2006 ; 37) bahwa Karater individu merupakan sikap dan minat serta kebutuhan yang di bawa dan mendukung seseorang atau individu dalam pelaksanaan kerja.

Tabel 3. Perbandingan t-tabel dengan t-hitung pengaruh inteligensi terhadap kinerja

\begin{tabular}{|c|c|c|c|}
\hline Variabel & t-tabel & t-hitung & keterangan \\
\hline Karakteristik individu (X1) & 1.671 & 1.819 & Signifikan \\
Intelegence (X2) & 1.671 & 2.658 & Signifikan \\
kompetensi sosial (X3) & 1.671 & 1.964 & Signifikan \\
\hline
\end{tabular}

a) Berdasarkan pada perbandingan antara t-hitung dengan t-tabel untuk variabel karakteristik Individu (X1) menunjukkan nilai t-hitung sebesar 1.819 > t-tabel 1.671. maka Ho ditolak dan $\mathrm{H} 1$ diterima. Artinya secara parsial variabel karakteristik individu (X1) berpengaruh signifikan terhadap variabel pengembangan karir dosen (Y2).

b) Berdasarkan pada perbandingan antara t-hitung dengan t-tabel untuk variabel Intellegence (X2) menunjukkan nilai t-hitung sebesar $2.658>\mathrm{t}-$ tabel 1.671. maka Ho ditolak dan $\mathrm{H} 1$ diterima. Artinya secara parsial variabel Intellegence (X2) berpengaruh signifikan terhadap variabel pengembangan karir dosen (Y2). 
c) Berdasarkan pada perbandingan antara t-hitung dengan t-tabel untuk variabel kompetensi sosial (X3) menunjukkan nilai t-hitung sebesar $1.964>$ t-tabel 1.671. maka Ho ditolak dan $\mathrm{H} 1$ diterima. Artinya secara parsial variabel kompetensi sosial (X3) berpengaruh signifikan terhadap variabel pengembangan karir dosen (Y2).

Hasil ini menunjukkan bahwa selain kinerja dipengaruhi oleh faktor karakteristik individu juga di pengaruhi oleh faktor kecerdasan baik itu kecerdasan intelektual, kecerdasan emosional, dan kecerdasan spritual yang dalam arti umum adalah suatu kemampuan yang membedakan kualitas orang yang satu dengan orang yang lain. Jadi semakin tinggi tingkat kecerdasan yang dimiliki oleh seseorang maka akan menghasil kinerja yang baik. Hal ini sejalan dengan apa yang diungkapkan oleh Wechsler (dalam Anastasi dan Urbina, 1997: 220) seorang ilmuwan dari Amerika adalah orang yang membuat test inteligensi WAIS dan WISC yang banyak digunakan diseluruh dunia. Ia mengemukakan bahwa inteligensi adalah kemampuan global yang dimiliki oleh individu agar bisa bertindak secara terarah dan berpikir secara bermakna serta bisa berinteraksi dengan lingkungan secara efisien.

5) Uji Hipotesis kedua (Uji F)

Tabel 4. Perbandingan f-tabel dengan f-hitung pengaruh karakteristik individu, intellegence, dan kompetensi sosial terhadap kinerja dosen. 
ANOVAb

\begin{tabular}{|l|r|r|r|r|r|}
\hline Model & $\begin{array}{c}\text { Sum of } \\
\text { Squares }\end{array}$ & Df & $\begin{array}{c}\text { Mean } \\
\text { Square }\end{array}$ & F & Sig. \\
\hline 1 Regression & 432.106 & 3 & 144.035 & 44.353 & $.000^{a}$ \\
Residual & 185.107 & 57 & 3.247 & & \\
Total & 617.213 & 60 & & & \\
\hline
\end{tabular}

a. Predictors: (Constant), kompetensi sosial, Karakteristik individu, intelegence

b. Dependent Variable: kinerja

Berdasarkan perbandingan nilai f-hitung dengan ftabel yaitu 44.353 > 2.76. maka dapat disimpulkan Ho ditolak dan $\mathrm{H} 1$ diterima. Artinya terdapat pengaruh secara simultan atau bersama-sama antara variabel karakteristik individu, intellegence, dan kompetensi sosial terhadap kinerja dosen.

Tabel 5. Perbandingan f-tabel dengan f-hitung pengaruh karakteristik individu, intellegence, dan kompetensi sosial terhadap pengembangan karir dosen.

ANOVA

\begin{tabular}{|c|c|c|c|c|c|}
\hline Model & $\begin{array}{l}\text { Sum of } \\
\text { Squares }\end{array}$ & Df & $\begin{array}{c}\text { Mean } \\
\text { Square }\end{array}$ & $\mathrm{F}$ & Sig. \\
\hline 1 Regression & 17.176 & 3 & 5.725 & 3.770 & $.005^{\mathrm{a}}$ \\
\hline Residual & 117.808 & 57 & 2.067 & & \\
\hline Total & 134.984 & 60 & & & \\
\hline
\end{tabular}

a. Predictors: (Constant), kompetensi sosial, Karakteristik individu, intelegence

b. Dependent Variable: pengembangan karir

Berdasarkan perbandingan nilai f-hitung dengan ftabel yaitu $3.770>2.76$. maka dapat disimpulkan Ho ditolak dan $\mathrm{H} 1$ diterima. Artinya terdapat pengaruh secara simultan atau bersama-sama antara variabel karakteristik individu, intellegence, 
dan kompetensi sosial terhadap pengembangan karir dosen.

Jadi jika seseorang memiliki tingkat kompetensi sosial yang tinggi maka akan sangat berpengaruh terhadap kinerjanya, sejalan dengan apa yang diungkapkan oleh Wibowo dalam Tinneke (2015) yang menjelaskan bahwa kompetensi berhubungan dengan apa yang dilakukan orang ditempat kerja pada berbagai tingkatan dan memperinci standar masing-masing tingkatan, mengidentifikasi karakteristik, pengetahuan dan keterampilan yang diperlukan oleh individual yang memungkinkan menjalankan tugas dan tanggung jawab secara efektif sehinggga mencapai standar kualitas professional dalam bekerja dan mencakup semua aspek catatan manajemen kinerja, keterampilan dan pengetahuan tertentu, sikap, komunikasi, aplikasi dan pengembangan.

\section{KESIMPULAN}

Berdasarkan hasil pembahasan dan pengamatan selama penelitian, maka dapat disimpulkan bahwa:

1. Variabel karakteristik individu berpengaruh secara parsial dan signifikan terhadap kinerja dosen. Kesimpulan ini didasarkan pada uji t. Dimana t-hitung $3.076>$ dari t-tabel 1.671 .

2. Variabel kecerdasan berpengaruh secara parsial dan signifikan terhadap kinerja dosen. Kesimpulan ini didasarkan pada uji t. Dimana t-hitung $2.532>$ dari t-tabel 1.671 . 
3. Variabel kompetensi sosial berpengaruh secara parsial dan signifikan terhadap kinerja dosen. Kesimpulan ini didasarkan pada uji t. Dimana t-hitung $5.770>$ dari t-tabel 1.671 .

4. Variabel karakteristik individu, kecerdasan, kompetensi sosial sama sama berpengaruh secara simultan terhadap kinerja dosen. Kesimpulan ini didasarkan pada nilai $\mathrm{f}$ hitung dengan f-tabel yaitu $44.353>2.76$.

5. Variabel karakteristik individu berpengaruh secara parsial dan signifikan terhadap pengembangan karir dosen. Kesimpulan ini didasarkan pada uji t. Dimana t-hitung $1.819>$ dari t-tabel 1.671 .

6. Variabel kecerdasan berpengaruh secara parsial dan signifikan terhadap pengembangan karir dosen. Kesimpulan ini didasarkan pada uji t. Dimana t-hitung 2.658> dari t-tabel 1.671 .

7. Variabel kompetensi sosial berpengaruh secara parsial dan signifikan terhadap pengembangan karir dosen. Kesimpulan ini didasarkan pada uji t. Dimana t-hitung 1.964 > dari t-tabel 1.671 .

8. Variabel karakteristik individu, kecerdasan, dan kompetensi sosial sama sama berpengaruh secara simultan terhadap pengembangan karir dosen. Kesimpulan ini didasarkan pada nilai f-hitung dengan f-tabel yaitu $3.770>2.76$. 
Qaiyim Asy’ari : Pengaruh Karakteristik Individu, Intelegensi dan Kompetensi Sosial

\section{DAFTAR PUSTAKA}

Ahmad Purba 1999, Emotional Intelligence, Seri Ayah Bunda, 26 Juli-8 Agustus, Dian Raya, Jakarta.

Anastasi, A, dan Urbina, S, 1997, Tes Psikologi (Psychological Testing), PT. Prehanllindo, Jakarta.

Arikunto, Suharsimi. 2006. Prosedur Penelitian Suatu Pendekatan Praktik. Jakarta: Rineka Cipta.

Ary Ginanjar Agustian, 2001, Rahasia Sukses Membangun Kecerdasan Emosi dan Spiritual (ESQ), Arga Wijaya Persada, Jakarta.

Berman, M, Developing SQ (Spiritual Intelligence) Throught ELT, http://www.eltnesletter.com, 12 Juni 2005.

Eckersley, R, 2000, Spirituality, Progress, Meaning, and Values, Paper Presented 3 Rd Annual Conference on Spirituality, Leadership, and Management, Ballarat, 4 December.

Enceng, Liestyodono dan Purwaningdyah, 2008. Meningkatkan Kompetensi Aparatur Pemerintah Daerah dalam Mewujudkan Good Governance. Jurnal Kebijakan dan Manajemen PNS. Vol 2 Juni 2008: 12-15.

Eysenck, H.J, and Kamin, L, 1981, Intelligence: The Batle For The Mind, Pan Book, London dan Sydney.

Fabiola Meirnayati Trihandini, 2005. Analisis Pengaruh Kecerdasan Intelektual, Kecerdasan Emosi dan Kecerdasan Spiritual terhadap Kinerja Karyawan (Studi Kasus di Hotel Horison Semarang). Semarang: tesis. Program Studi Magister Manajemen Program Pascasarjana Universitas Diponegoro Semarang.

Ghazali, Imam. 2011. Aplikasi Analisis Multivarate dengan Program IBM SPSS 19. Semarang: Badan Penerbit Universitas Diponogoro.

Gibson, Ivancevich dan Donnelly, 1997. Organisasi: Perilaku, Struktur, Proses Jilid 1, Erlangga, Jakarta. 
Goleman, D, 2000, Kecerdasan Emosi: Mengapa Emotional Intelligence Lebih Tinggi Daripada IQ, Alih Bahasa: T. Hermay, PT. Gramedia Pustaka Utama, Jakarta.

Hoffman, E, 2002, Psychological Testing At Work, Mc Graw Hill, New York.

Idrus, D, 2000, Spirituality at Work: A Conceptualization and Measure, Journal of Management Inguiry, Vo.8, No.2, pp.134-45.

Joseph, G, 1978, Interpreting Psychological Test Data, Vol.1, New York VNR.

Mangkunegara. 2004. Manajemen Sumber Daya Manusia, Remaja Rosdakarya, Bandung.

Maria Sumediyani, 2002, Kecerdasan Spiritual dan Problema Bangsa Ini, www.google.com, 12 Juni 2005.

Mathis, Robert L. dan John H. Jackson, 2006. Manajemen Sumber Daya Manusia). Edisi 10. Jakarta: Salemba Empat.

Meyer, J, 2000, EQ dan Kesuksesan Kerja, http://www.epsikologi.com, 12 Desember 2004.

Mitroff, L.I, and Denton, E,A, 1999, A Study of Spiritualty in The Work Place, Sloan Management Review, Vol.40, No.4, pp.8392.

Muchlas, 1998. Perilaku Organisasi Jilid 2 Edisi 1, Magister Manajemen Rumah Sakit UGM, Yogyakarta.

Mudawi. 2015. Persepsi Akademisi mengenai Akuntansi Forensik. Bangkalan; Skripsi Universitas Trunojoyo Madura.

Muhammad Idrus, 2002, Kecerdasan Spiritual Mahasiswa Yogyakarta, Psikologi Phronesis, Jurnal Ilmiah dan Terapan, Vo.4, No.8, Desember 2002.

Nasution, zahriany, ade ira. 2009. Pengaruh Karakteristik Individu Dan Psikologis Terhadap Kinerja Perawat Dalam Kelengkapan Rekam Medis Di Ruang Rawat Inap Rumah Sakit Umum Dr. Pirngadi Medan. Medan: Universitas Sumatera Utara. 
Qaiyim Asy'ari : Pengaruh Karakteristik Individu, Intelegensi dan Kompetensi Sosial

Patton, P, 1998, Kecerdasan Emosional di Tempat Kerja, Alih Bahasa: Zaini Dahlan, Pustaka Delaprata, Jakarta.

Spencer, Lyle M. and Signe M. Spencer, 1993. Competence work: Model for superior performance. John Wiley and Sons, Inc.

Sugeng, Iman. 2002. Mengukur dan mengelola intellectual capital. Paradigma baru manajemen sumber daya manusia. Editor A. Usmara. Penerbit amara books.

Sugiyono. 2011. Metode Penelitian Kuantitatif, Kualitatif dan R\&D. Bandung: Alfabeta.

Sumadi Suryabrata, 1998, Pembimbing Ke Psikodiagnostik II, Rake Sarasin, Yogyakarta.

Sutardjo. A Wiamiharja, 2003, Keeratan Hubungan Antara Kecerdasan, Kemauan dan Prestasi Kerja, Jurnal Psikologi, Vol.11, No1, Maret 2003.

Wibowo, 2008. Manajemen Kinerja. Jakarta: PT Raja Grafindo Persada.

Yuliana. 2015. Pengaruh Kepemimpinan dan Dukungan Sosial Terhadap Motivasi Kerja Karyawan Pada PT Niaga Tama Raharja Kabupaten Bangkalan. Skripsi Universitas Trunojoyo Madura.

Zohar, D, Marshal, I, 2000, SQ (Spiritual Intelligence): The Ultimate Intelligence, Blomsburry Publishing, London. 